\title{
The Effect of Availability of School and Distance to School on Children's Time Allocation in Ghana
}

\section{Daniela Vuri}

Abstract. In this paper we present evidence on the impact of distance to school and school availability on households' decisions concerning time allocation of primary-age children between work, schooling, and household chores activities using data from the Ghana Living Standard Survey 1998-99. Our results indicate that the increased and eased access to school has a well-defined impact on children's time use. In particular, reducing the distance to primary school encourages children school attendance and reduces children work. Interestingly, the distance to middle school discourages children's work and boosts household chores activities. Moreover, the availability of both primary and middle schools has a positive effect on schooling decisions, and having a primary school nearby discourages household chores activity. Our results are robust to controlling for the endogeneity of school placement and per capita expenditures. We also find that household decisions about children's time use differ by children's sex, suggesting that girls may be differently responsive to policy measures aimed at reducing work and household chores activities and at increasing their school attendance.

\section{Introduction}

There is almost universal agreement that child labor is undesirable because it negatively affects a child's future welfare in exchange of immediate benefit. The benefits to the household of sending their children to work are the income of the children and the reduced schooling expenditures for not sending them to school. In addition, there are clear spillover effects: more educated children once adults will raise healthier children affected by lower morbidity and lower mortality rates. However, work early in life has a cost for children in terms of lower future earnings when entering the labor market as adults due to the lower educational attainment obtained during childhood.

Although it has been widely acknowledged that work may be harmful for children, child labor is a widespread phenomenon in the developing world. The International Labor Office (ILO) (2006) estimates that about 191 million children aged 5-14 years were working in 2004. Of these working children, 74 million were in hazardous work, and 108 million were below the age of 12 years. Moreover, the United Nations Educational, Scientific and Cultural Organization (UNESCO) estimates that about one out of five primary-school-aged children were not enrolled in school. Regionally, the ILO estimates that Asia has the largest number of child

Daniela Vuri, University of Rome Tor Vergata, Department of Financial Economics and Quantitative Methods, Faculty of Economics, Via Columbia 2, 00133 Roma, Italy. Tel.: +39 067259 5916; Fax: +39 06 2040219; E-mail: daniela.vuri@uniroma2.it.

We would like to thank Furio Camillo Rosati for many helpful discussions, an anonymous referee for useful comments and suggestions, Lorenzo Guarcello for clarification on the data, and the World Bank for financial support. Any error is the author's sole responsibility. 
workers, but the incidence is highest in Africa (about 1 in 4 children younger than 15 years are economically active in Africa, compared with 1 in 5 in the Asia-Pacific region, and 1 in 20 in Latin America and the Caribbean). For these children, the main cost of work is represented by the reduction in their human capital investment and this occurs primarily because child work interferes with schooling, leading to the not-attendance or early drop-out and entry into full-time work.

School represents the most important means of drawing children away from the labor market (ILO, 2002). Two channels have been mainly used to improve access to education for poor households in developing countries: investments in infrastructure on one side (supply side) and subsidies to investment in education to the poor and school quality improvement on the other (demand side). The relative importance of school supply versus household demand factors has serious implications for education policy. ${ }^{1}$ In many developing countries, especially in rural areas, supply constraints, such as difficult access to schools in terms of high distance to the nearest school or high travel costs, might have a non-negligible effect on children's time allocation. Furthermore, schooling costs may not be constant throughout the education cycle, and supply constraints on middle and secondary education could be part of the reason why so many children in developing countries do not attend school at all or drop out of the primary school (Lavy, 1996). In addition, not only direct costs (tuition fees and travel time) but also the indirect costs of schooling (the opportunity costs of time spent in school instead of working) can vary over the course of the schooling cycle. It is therefore of crucial importance to understand the dynamics of households' decisions about their children's activities. If not, public investments in education are not likely to reach the goal to get children into classrooms and to reduce child labor.

In this paper we exploit the role of specific supply-side factors (and in particular availability of school and distance to school) in determining households' decisions about time use of primary-school-aged children in Ghana. We are not the first ones to investigate empirically the effect of availability of school and distance to school on children's work and schooling, but we will extend previous works by including children's household chores activity in the parental decision set. ${ }^{2,3}$ We explicitly recognize that, although the definition of child work used in the literature usually excludes household chores such as fetching wood, water, cooking, cleaning, and child care and similar activities undertaken by a boy or a girl in the household, the implication for child welfare of being engaged in these activities might not be less important than work because they could interfere with formal education as much as work, especially for girls. ${ }^{4}$ In our analysis we investigate how households respond to the presence of schools and variations in the travel distance to schools when deciding about their child(ren) time allocation between schooling, work, and household chores activities. We also explore whether family choices differ by child(ren) sex. Finally, we deal with two important problems related to the endogeneity of school placements and per capita expenditure and we check whether our results are robust to controlling for these two potential sources of bias.

Our empirical analysis shows that reducing the distance to primary school encourages children school attendance and reduces work. Similarly, improved access to middle schools through shorter travel distances helps to reduce child work. The availability of primary school increases school attendance and discourages household chores activities. The availability of middle school has an effect only on school attendance. Finally, there are gender differences in the effects of availability of school and distance to schools on children time allocation, pointing to the need for different policy approaches for girls and boys.

The structure of this paper is as follows. Section 2 briefly reviews the relevant literature on this topic in less developed countries. Section 3 discusses the theoretical framework, Section 4 
presents the econometric models used in this paper to analyse the joint probability and trade-off between child work, school attendance, and household chores activities among primary-school-aged children. Section 5 describes the data used and the selected variables. Section 6 presents the regression results, whereas Section 7 discusses some robustness checks. Section 8 offers a provisional conclusion.

\section{Literature review}

Starting from the pioneering work of Rosenzweig and Evenson (1977), where the joint family decision regarding fertility and children's time allocated to schooling and work are analysed by fitting a simultaneous equations model to Indian data, a large number of other papers have followed on this subject analysing the relationship between child work, school attendance, fertility, and other household characteristics (Cigno and Rosati, 2005; Patrinos and Psacharopoulos, 1995; Psacharopoulos and Yang, 1991; Rodgers and Standing, 1981a, 1981b; Silva de la Luz, 1981; Singh and Schuh, 1986; Tienda, 1979 for a book review on child labor; Brown et al. 2002 and Edmonds, 2007 for article reviews on child labor; Orazem and Gunnarsson, 2004 for an article review on the impact of child work on school attainment). There are several papers on the effect of supply constraints on young children's labor supply and school enrollment or attendance in developing countries. Some studies find a link between measured schooling costs and child work. Hazarika and Bedi (2003) examine the separate effects of schooling costs upon child work within the household (intra-household) and child work in the labor market (extra-household) in rural Pakistan. They find that extra-household child work and schooling costs are positively related whereas intra-household child work is insensitive to changes in the costs of schooling. Given that intra-household labor is a relevant part of child work, these findings cast doubt on the efficacy of a school costs reduction policy in reducing child labor. In urban Bolivia, Cartwright and Patrinos (1999) find a strong positive relationship between schooling costs and child work participation. In contrast, Cartwright (1999) shows that higher school costs are associated with a lower probability of working in Colombia. Edmonds et al. (2007) demonstrate that the relative declines in schooling and increases in work associated with India's tariff reforms are smaller in areas where schooling is less expensive.

There are few papers that have specifically looked at one dimension of the schooling costs, namely the effect of travel time or distance to school on children educational and work outcomes. Grootaert (1999) reports that child work force participation in rural Cote d'Ivoire is responsive to distance to school but the same effect is not found when urban Cote d'Ivoire is considered. Akabayashi and Psacharopoulos (1999) report that children work more and longer in areas with lower concentration of schools. In particular, distance to the closest public primary school is negatively related to hours of work. Lavy (1996) finds that the supply constraints on middle and secondary schools are as relevant as supply constraints on primary schools in increasing school enrollment and children attainment. This highlights the importance of improving not only the quality of primary schools but also the access and the quality of higher-order schools. Analysing both the supply and the demand factors affecting primaryschool enrollment, Handa (2002) finds that school access on the supply side and adult education on the demand side are the most important determinants of primary-school enrollment. In particular, reducing the travel time to school seems to be particularly effective among poorer households. Kondylis and Manacorda (2006) are among the firsts to study the effect of distance to school on the children's joint decisions of working and attending school in 
Tanzania, but they do not consider household chores activities. They find that after controlling for unobserved differences across villages and observed determinants of child work, higher distance to schools discourages school attendance but not work activities. Considering explicitly all the possible combinations of work and school choices, they find that the above result is mainly driven by the individual shift from a combination of work and schooling to full-time work. Therefore, improving access to schools in rural areas will most likely increase school attendance but it is unlikely to reduce children's employment. Differently from the previous study, Hazarika and Bedi (2006) find that an increase in schooling costs (both in terms of direct costs and in terms of distance to school) has a positive impact on children's propensity to work and a negative effect on their probability of attending school (but the two choices are not jointly analysed).

\section{Theoretical framework}

The theoretical framework for this analysis is derived from a standard Becker household production model (Becker, 1965), which has found an application in Rosenzweig and Evenson (1977), where multiple activities of children in developing countries are taken into account. Empirical work originating from this framework highlights the importance of factors related to: individual characteristics of the child such as gender and age; family structure and the relative position in terms of age of the child within the family; family income and parental labor force participation; labor market conditions such as the wages of children and adults; community infrastructure, such as the supply of school, the presence of water, electricity, market, road, postal office, telephone, etc. We use this utility-maximizing framework to model the household choices regarding children school and work activities as a function of individual, parental, household, and community characteristics.

In particular, when analysing the factors influencing household decisions concerning children's time use, it is assumed that parents make their choices on the basis of the relative costs and benefits of their children work (or alternatively children education). ${ }^{5}$ The returns to child labor have to be found in the learning-by-doing process and skill accumulation. This is especially true in rural areas where formal education is not attractive for households due to the lack of opportunities in the formal sector, whereas most skills can be acquired directly on the job. In addition, for households that are resource-constrained, child labor is often used as a buffer against insecurity and uncertainty, and in general returns to child labor may constitute a substantial contribution to household income, up to 20 per cent of total household income (UCW, 2003). Grootaert and Kanbur (1995) also mention that child labor can be perceived as a process of socialization, and working rather than education provides a child the skills required for being employable.

There are several factors expected to increase the benefits from education, those directly aimed at increasing the returns to education (school quality, employment prospects, etc.) and those aimed at reducing the costs of education (fees, distance to school, etc.). In particular, school accessibility represents an indirect cost of education and it greatly affects households' decisions concerning children's time use. Therefore, school expansion seems to be a necessary condition to reduce child labor. At the same time, secondary school availability might be also relevant in determining parents' decisions about time allocation of primary-school-aged children, with the effect of increasing school attendance and educational attainment and at the same time reducing their work.

These effects are likely to be differentiated depending on the characteristics of the household and of the child. For example, parental choices over their children's time use and returns to 
education, as well as child productivity, can depend on children's age and gender, but also on parental characteristics (parental education and their presence in the household). Similarly, the level of household income and wealth is likely to influence the relative size of the income and substitution effects. Also household composition has an important effect on children's time use but the sign of this effect is indeterminate a priori. In general, the presence of very young children in the household may lead to a higher probability of working (either by performing economic activity if it is necessary to increase household income or by doing household chores if child care activities are needed). On the contrary, the presence of older children may increase children's work if more work is created, or increase school attendance if older children act as substitutes. Differences in labor market and educational opportunities across regions may also affect household decisions.

\section{Empirical strategy}

This paper aims at estimating the effects of availability of school and distance to school on both children's propensity to work and children's propensity to attend school, controlling for a set of demand and supply-side variables. We initially focus on child market economic activity and school attendance. We assume that a child specializes either in school, or in work, or combines both work and schooling, or does neither activities, like in Kondylis and Manacorda (2006). We treat schooling and work possibilities as interdependent choices and we use a bivariate probit model to test the likelihood of children working and going to school, given several individual, household characteristics, and community variables.

In the bivariate probit, let the latent variable work $_{i}^{*}$ identify if a child works in economic activity and attend $_{i}^{*}$ if she/he attends school. ${ }^{6}$ Therefore, the specification for a two-equation model is

$$
\begin{aligned}
& \text { work }_{i}^{*}=\alpha_{1}+\beta_{1} \text { distprim }_{i}+\beta_{2} \text { distmid }_{i}+X_{i} \gamma_{1}+F_{\mathrm{c}} \delta_{1}+\varepsilon_{1 i}, \quad \text { work }=1 \text { if } \text { work }_{i}^{*}>0 \\
& \text { attend }_{i}^{*}=\alpha_{2}+\beta_{3} \text { distprim }_{i}+\beta_{4} \text { distmid }_{i}+X_{i} \gamma_{2}+F_{\mathrm{c}} \delta_{2}+\varepsilon_{2 i}, \quad \text { attend }=1 \text { if } \text { attend }_{i}^{*}>0,
\end{aligned}
$$

where distprim $_{i}$ and distmid $_{i}$ measure the travel distance to primary school and middle school, respectively, $X_{i}$ indicates individual control variables, and $F_{\mathrm{c}}$ indicates dummies for the presence of primary, middle, and secondary schools in the community plus other variables measured at the community level; finally $\varepsilon_{1 i}$ and $\varepsilon_{2 i}$ are independent and identically distributed error term.

As we are interested in the effect of school distance and school availability on households' decisions concerning their children school attendance and work, our attention is focused on the variables distprim $_{i}$, distmid $i$ and the presence of schools of any type included in $F_{\mathrm{c}}$. The data used [Ghana Living Standard Survey 1998-99 (GLSS)] provide two measures of school distance that can be both considered as measures of travel costs. The first measure is collected at the community level and gives information on distances in kilometers to the nearest primary, middle, and secondary schools for those communities that do not have a school. ${ }^{7}$ Out of the 223 communities in the survey, about 84 per cent declare to have a primary school in the community, 60 per cent have a middle school, and only 11 per cent have a secondary or technical school in the village. Given that the distance in kilometers is provided only for communities with no schools, the distance measure is assumed to be zero for communities having schools. As a consequence, this variable has very small variability across individuals of 
primary-school age belonging to the same community, and only slightly more for middleschool-aged children. For this reason, we prefer using the second measure of school distance collected at the individual level. In particular, for each household member having attended school at any time during the past 12 months it is asked the daily time expressed in hours and minutes needed to reach school. Using individual travel school distance rather than community distance to school we can capture the fact that, within communities, households may live in rather widespread areas around schools, which is extremely important in rural areas. Information on travel distance to school is available for 83 per cent of children. For the remaining 17 per cent not attending school, we build a measure of potential travel distance by attributing the actual travel distance of the same-age sibling(s) if there is at least one sibling attending school. If there are no siblings of the same age group in the household or none of them is attending school, we impute the average distance of similar age children in the community (or in the district if no children living in the same community attend school). Moreover, we also build a potential travel distance from middle school for primary-schoolaged children. For this purpose, we select children aged between 13 and 17 years and we use the same procedure to attribute the potential travel distance from middle school to primaryschool-aged children. ${ }^{8}$

Under the assumption that $\varepsilon_{1 i}$ and $\varepsilon_{2 i}$ are jointly normally distributed, equations [1] and [2] can be estimated simultaneously by maximum likelihood. Coefficients $\beta_{1}, \beta_{2}, \beta_{3}$, and $\beta_{4}$ are of primary interest and we expect $\beta_{1}, \beta_{2}$ to be positive, and $\beta_{3}$ and $\beta_{4}$ to be negative. Similarly, the availability of primary, middle, and secondary schools are expected to have a positive impact on the probability of attending school and a negative one on the probability of working. However, as mentioned in Section 1, we recognize that household chores may be not less demanding or less important for families and can conflict with formal education as much as work activities, or even more in case of girls. As a matter of fact, a consistent part of child labor in rural areas consists of household chores and ignoring this type of work may lead to the erroneous conclusion that the problem of child work in rural areas is marginal. For this reason, we enrich the model by analysing children's time allocation in school, work, and household chores. When household chores are taken into account, the following equation is estimated jointly with equations [1] and [2]:

$$
\text { chores }_{i}^{*}=\alpha_{3}+\beta_{5} \text { distprim }_{i}+\beta_{6} \text { distmid }_{i}+X_{i} \gamma_{3}+F_{\mathrm{c}} \delta_{3}+\varepsilon_{3 i}, \quad \text { chores }=1 \text { if } \text { chores }_{i}^{*}>0 .
$$

In order to account for the dichotomous nature of work $_{i}$, attend , $_{i}$ and chores $_{i}$ variables, we use a trivariate probit model. It is assumed that $\varepsilon_{1 i}, \varepsilon_{2 i}$, and $\varepsilon_{3 i}$ are error terms distributed as multivariate normal, each with a mean of zero and a variance-covariance matrix $\mathrm{V}$, which has unit diagonal elements and off-diagonal elements equal to $\rho_{j k}=\rho_{k j}$. The evaluation of the likelihood function requires the computation of trivariate normal integrals, which are approximated via the Geweke-Hajivassiliou-Keane (GHK) smooth recursive simulator (Hajivassiliou et al., 1996). ${ }^{9}$

There are two problems that could arise in our estimates and potentially bias the results. One is the use of travel distances to proxy the costs of education, which may create a problem of endogeneity if schools are not randomly allocated over the country. The second is the endogeneity of household per capita expenditure. In our estimates we use total per capita household consumption expenditures as, for households that cannot borrow, consumption is highly correlated with income. However, consumption might be endogenous in a regression explaining human capital investment. ${ }^{10}$ We will deal with these problems in Section 7 using an instrumental variable approach to estimate our models. 


\section{Data and variables: the GLSS}

The empirical analysis is conducted using data from the GLSS covering a random sample of 6,000 households and more than 26,000 household members. The present study focuses on 3,699 rural households providing information on demographic characteristics, health and fertility behavior, education, employment and time use, income, consumption and expenditure. The GLSS also includes information on family structure and dwelling characteristics. The survey is complemented by a community questionnaire identifying the economic infrastructure, education, and health facilities existing in the villages. As community data were collected only in rural areas, we focus on households living in such areas.

According to Ghana's educational system children start elementary school when 6 years old, middle school when 12 years old, and secondary school when 15 years old. We restrict our sample to children between the ages of 7 and 12, which corresponds to the age children are usually enrolled in primary school. ${ }^{11}$ This is a critical period for children because they are more likely to drop out of school or not to enroll in school at all. There are several reasons why it might be the case. Recent evidence suggests that in Ghana primary school is only used to access to more advanced schooling. Glewwe (1990) has shown that the lowest rates of return to schooling in Ghana are found at the primary-school level, and the highest are found in post-primary-schooling levels. The low return to primary schooling can be explained by the low achievement scores of primary-school students (Glewwe and Jacoby, 1994). Glewwe and Jacoby (1994) provide mean scores for mathematics and reading tests (eight questions each). Even after 6 years of schooling, the mean scores, especially in the reading test, are very low, showing that students do not acquire much human capital in primary school. Scores at the middle-school level are slightly higher but still low in absolute term, which implies that learning in Ghana starts in middle school and that the completion of primary school is only a threshold required to start accumulating human capital. As a matter of fact, the market treats primary level of schooling as no schooling. Moreover, Lavy (1996) advocates supply constraints on middle and secondary education such as difficult access to schools (the distance from the nearest school, high travel costs, boarding fees) as part of the reason why so many children in developing countries do not attend school at all or drop out of primary school. He finds evidence that the cost of advanced levels of education influences schooling decisions at the primary-school level in Ghana. Similarly, Canagarajah and Coulombe (1997) show that household welfare is strongly related to school participation trends. Many parents have to pay some amount for tuition and other direct costs in terms of uniform and books. In 1992 in Ghana per capita costs for publicly provided primary education accounted for more than 15 per cent of households mean per capita expenditure, thus indicating the burden of school expenses on poor households. This pushed parents in pulling their children out of school and sending them to work. Also past studies (Demery et al., 1995) have found that the public subsidies benefit the urban non-poor more than the rural poor. The nature of labor markets and the low returns to education have made education less attractive for many parents, especially in rural areas, where formal education makes very little difference given that formal sector opportunities are limited and most skills are acquired by the learning-by-doing principle. Working rather than education is believed to enable a child to get acquainted with the skills required for being employable (Grootaert and Kanbur, 1995).

After deleting observations with missing values in the main covariates, we have a sample of 3,143 primary-school-aged children, belonging to 1,917 households. ${ }^{12}$

Regarding the dependent variables, school attendance is a dummy equal to one if the child has declared to have attended school at any time during the past 12 months, ${ }^{13}$ child work is a 
dummy equal to one if, during the past 12 months, the child has declared to have worked for a wage or in-kind payment, or has performed unpaid work for an enterprise belonging to a member of the household. Non-economic activity (household chores hereafter) is a dummy equal to one if the child has declared to have spent time on housekeeping activities including fetching wood, fetching water, ironing clothes, taking care of children, washing motor vehicles, sweeping, disposing of garbage, cooking, marketing or shopping, or running errands for at least 2 hours a day. ${ }^{14}$

The explanatory variables include school variables (the availability of primary, middle, and secondary schools, the distance from primary and middle schools, and the school costs), ${ }^{15}$ measures of children, parents, and household characteristics, family structure, community characteristics, and area dummies. In particular, children's characteristics include age and whether or not the child is the son or the daughter (versus other relative) of the household head.

Parental characteristics include three educational variables corresponding to no education, up to primary school, and above primary school. Dummy variables indicate whether the father and the mother reside in or are absent from the household. ${ }^{16}$

Household characteristics include several proxies for the wealth and living standard of the household, i.e. the per capita consumption expenditure (in $\log$ ) and variables for the existence of private bathroom, electricity, drinking water in the dwelling, and cement walls. We also include six dummies for religion, namely Catholic, Protestant, Other Christian, Muslim, Animist, and no religion.

Household composition variables are included because different family members may act as substitutes for children in household duties or may create more work in the household. In particular, we have variables for the number of siblings aged $0-6$, number of additional siblings aged 7-12, number of siblings aged 13-17, number of male adults aged between 18 and 59 , number of female adults aged 18-59, number of elderly aged 60 or more.

Among the communities variables we include having a motorable road, pipe-borne water, public transports, an agricultural extension centre, tractors, an agricultural extension officer, ${ }^{17}$ a cooperative, and the use of chemical fertilizers or insecticides. Because, as observed by Lavy (1996), the majority of workers in Ghana are farmers, the return to human capital in rural areas is strictly linked to the presence of machinery, chemical inputs, and extension services. Therefore, by including these variables we should be able to control for regional variation in the returns to human capital. Ideally, we would like to include the market child wage rate (at the community level) in order to capture the opportunity cost of time spent at school. However, as we have many missing values in this variable, we include the adult male wage rate collected at the community level as proxy for child's wage.

Finally, we have four dummies for area of residence, namely urban area, rural costal, rural forest, and rural Savannah in order to control for regional fixed effects. Table A1 in the Appendix presents the mean and standard deviations of the variables used in the empirical analysis.

\section{Regression results}

\subsection{The working and schooling decisions in Ghana}

The marginal effects for the bivariate probit estimates of the school attendance and work participation equations obtained for a sample of rural children aged 7-12 in Ghana are 
reported in Tables 1 and $2 .{ }^{18}$ We report the effect of availability of school and distance to school on the joint probabilities of working and attending school (work and school, work and no school, no work and school, and no school and no work). We use two different models. In Table 1 we consider the availability of primary, middle, and secondary schools in the community. In Table 2 we also add the travel distance to primary and middle schools expressed in 10 minutes to test the relevance of the time component in the household's decision to send their child(ren) to school and/or to work. As mentioned in Section 1, the variables related to the availability of school and the distance to schools proxy for the costs of education. In both tables we control for the average community schooling costs, child age and sex, a dummy for being the son (daughter) of the households head, dummies for the number of siblings in different age groups (0-6, 7-12, and 13-17), number of adults in the households (female aged 18-59, male aged 18-59, and adults over 60), presence of parents in the household and their level of education, religion, per capita consumption expenditure (in logarithm), and dummies for the presence of water, electricity, private toilet, cement walls in the dwelling, and value of livestocks. Among the community variables we include average men daily wage, having a motorable road, pipe-borne water, public transport, an agricultural extension centre, an agricultural extension officer, a cooperative, tractors in the community, and using chemical fertilizer or insecticides. Finally, we include a set of area dummies to control for the demand patterns of labor marketing different areas.

From Table 1 it turns out that the availability of primary schools has a positive and significant impact on the probability that a child combines work and schooling and attends school on a full-time basis (3.1 and 4.5 percentage points, respectively), whereas it reduces the probability of a child being inactive by 6.5 percentage points. The availability of middle school in the community instead has a strong positive impact on the probability of a child being full-time at school (6.4 percentage points) and discourages child being inactive by 5.1 percentage points and working full-time by 2.0 percentage points. On the contrary, the availability of secondary school does not have a significant impact on children's time allocation. Therefore, it is mainly the availability of middle school that influences full-time investment in education for households with primary-school-aged children. In other words, having a primary school in the village makes it easier for children to work and study simultaneously and prevent them from being idle at home, whereas the eased access to lower secondary education (middle school) may push parents to invest more on their offspring's education from the beginning of their children's schooling life. Overall, these results imply that the increase in schooling costs, as represented by the absence of schools in the community, in particular middle schools, affects negatively children's educational attainment.

In Table 2, we include an additional measure of educational costs, namely the travel distance to primary and middle schools. The variables related to travel distance to primary school yield interesting results: the more distant the school the less likely a child to attend school ( 0.4 percentage points) and more likely to work or to combine work and school (by 0.1 and 0.2 percentage points, respectively, for each additional 10 minutes of travel). The distance from middle school has a positive effect on the probability of a child attending school (0.3 percentage points), whereas it has a significant negative effect on the probability of combining work and school ( 0.3 percentage points) and to work ( 0.1 percentage points) (a similar result can be found in Deb and Rosati, 2002). The results concerning the availability of schools in the community do not change with respect to Table $1 .{ }^{19}$

Overall these results suggest that the longer the distance to primary school the more difficult for children to attend school, but the presence of schools (especially middle) encourages school attendance on a full-time basis. The distance to middle school instead encourages 
Table 1. Marginal effects of the bivariate probit estimates of children working and attending school

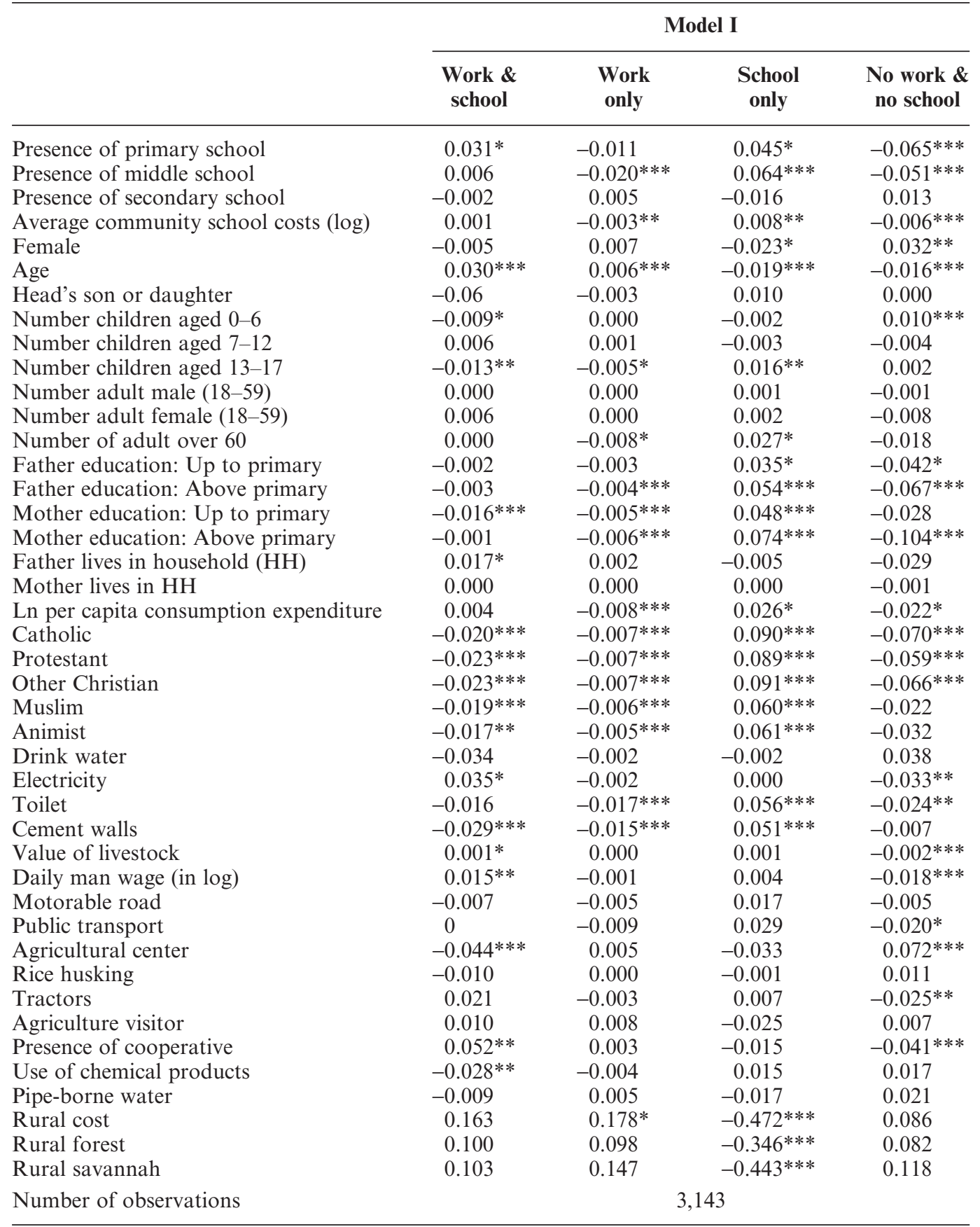

Notes: Omitted categories are: father no education or missing, mother no education or missing, no religion, other urban area. Partial derivatives for continuous variables are evaluated at their sample means, whereas dummy variables are evaluated for a change from zero to one. Standard errors are clustered by communities. Symbols: *** significant at 1 per cent; ** significant at 5 per cent; ${ }^{*}$ significant at 10 per cent. 
Table 2. Marginal effects of the bivariate probit estimates of children working and attending school

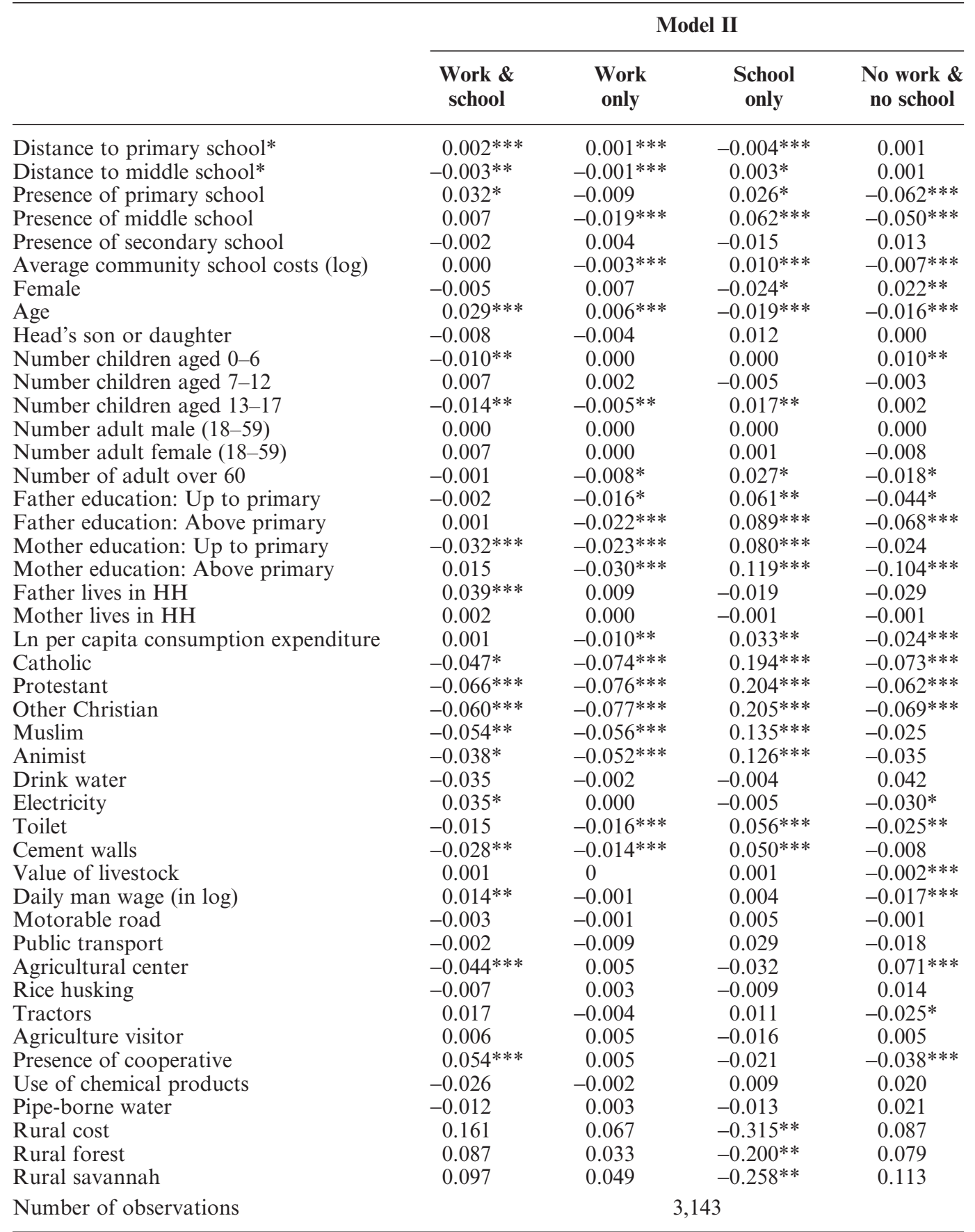

Notes: Omitted categories are: father no education or missing, mother no education or missing, no religion, other urban area. Partial derivatives for continuous variables are evaluated at their sample means, whereas dummy variables are evaluated for a change from zero to one. Standard errors are clustered by communities. Symbols: $* * *$ significant at 1 per cent; $* *$ significant at 5 per cent; ${ }^{*}$ significant at 10 per cent. 
school attendance of primary-school-aged children and discourages work (both in combination with school and on a full-time basis). When planning a long-term investment on their primary-school-aged children, parents look at the availability of school infrastructures and to travel distance (both to primary and to middle schools). Given that the returns to education tend to be higher for secondary than for primary education, parents may have a higher incentive to send their children to primary school rather than to work, if children may also have access to higher education. If the middle school is available in the community, the distance to middle school seems to impose a choice on the household who prefers to invest on children's education and not send them to work.

Concerning the other variables, we find that high school costs increase school attendance. This result might seem at odd with what expected because schooling expenditure should act as a deterrent on school participation. However, the same result for Ghana has been found in Canagarajah and Coulombe (1997) and Demery et al. (1995). This result can be explained if the school expenditure variable is considered as a proxy for good quality education in exchange of an official fee, given that the poor quality of teaching and teacher absenteeism have been often advocated as important reasons for not sending kids to school (Norton et al., 1995). Consistently, the school expenditure has a negative effect on the probability of child work (0.3 percentage points).

Girls are more likely to be at home neither working nor attending school (2.2 percentage points) and less likely to attend school (2.4 percentage points) ${ }^{20}$ However, the data could tell us a different story about the effect of gender when household chores are explicitly taken into account. We will come back to this point at the end of this section and again in Section 6.2. Age has a positive effect only on the probability of children combining work and school (2.9 percentage points) and working (0.6 percentage points) and a negative one on the probability of attending school (1.9 percentage points) and of being inactive at home (1.6 percentage points). It has been argued that the presence, the age, and the gender of siblings have a strong effect on schooling and working patterns of household members (Chernichovsky, 1985). Among the variables included to capture the household composition, the variables that turn out to be significant on a child probability of working and attending school are only the number of siblings aged $0-6$, which reduces the probability of primary-school-aged children combining work and school by 1.0 percentage points, and the number of siblings aged 13-17, which has a negative effect on the odds of combining work and school (1.4 percentage points), of working ( 0.5 percentage points), and a positive effect on the probability of attending school (1.7 percentage points). Moreover, each additional sibling aged $0-6$ increases the probability that a child is inactive by 1.0 percentage points, likely due to the need of child care provision. Finally, the presence of adults over 60 years of age reduces the probability of a child being inactive by 1.8 percentage points, likely because they may act as substitutes of young children at least for light houseworks, and the probability of exclusively working ( 0.8 percentage points), whereas it encourages full-time school attendance (2.7 percentage points).

Our estimations also show that father's education influences children work and schooling participation with an effect increasing with educational level. In particular, having a father with (up to primary) more than a primary-school diploma increases the probability of a child attending full-time school by (6.1) 8.9 percentage points (the reference category is being illiterate or missing). Moreover, educated fathers are less likely to make their children exclusively working or being inactive. If the father is present in the household, children are 3.9 percentage points more likely to combine work and school. This effect could be due to the fact that, as mentioned above, most workers are farmers in Ghana and children may 
perform unpaid work for the family business. Concerning mothers educational status, we see that a child with mother having a (more than) primary-school diploma is 8.0 percentage points (11.9 percentage points) more likely to go full-time to school, a child whose mother has a primary-school education is 3.2 percentage points less likely to work and attend school, whereas a child whose mother has more than primary school is 10.4 percentage points less likely to be inactive. Finally, the higher the mother's educational level, the lower the probability that a child works full-time. In general, parental education has a stronger positive effect on children school participation than on work decisions and mother's education has a bigger effect than father's education. There are at least two explanations for these results: (i) more educated mothers have bigger bargaining power inside the households leading to a positive effect on children's welfare if mothers care more for their children than fathers (Thomas, 1990); and (ii) more educated parents know better the returns to education and this could induce them to help their children to pursue this choice (Guarcello et al., 2005b).

The income effect captured through the per capita consumption expenditure variable is negative and significant on the probability of a child being inactive and working (2.4 and 1.0 percentage points, respectively), suggesting that richer families tend to keep their children busy in some activities. Not surprisingly, we find a positive income effect on child schooling (3.3 percentage points), as observed in other countries (see Behrman and Knowles, 1999 and Duraisamy, 2002 among others).

Religious dummies do matter both for child work force participation and for school attendance. In particular, all religious group dummies are significantly different from the reference group (not being religious). Catholics are 19.4 percentage points, Protestants 20.4 percentage points, Other Christians 20.5 percentage points, Muslims 13.5 percentage points, and Animists 12.6 percentage points more likely to send their children full-time to school. In a symmetric way, all the religious groups are less likely to make their children work, combine school and work, or be inactive at home. This suggests that religion may have a significant influence not only on the value of education in societies but also on the facilities that they provide through fees or subsidized education facilities, which represent an incentive for parents to send their children to school. Not by chance, primary schools in Ghana are often run by Churches or Church organization, which play a leading role in encouraging school participation behavior. When looking at the wealth proxies (measured by having drink water, electricity, toilet, and cement walls in the dwelling, and the value of livestock), we find that in general wealthier families prefer to send their children to school and discourage children from working or being inactive.

Concerning the variables that measure the variations across regions in the return to human capital, the existence of a cooperative in the village is positively correlated with a child attending school and working (5.4 percentage points) and negatively correlated with being inactive (3.8 percentage points). This result is consistent with the view that many children work in their family business, which makes it easier for them to reconcile school and work. The adult agricultural wage rate increases a child probability of jointly attending school and working by 1.4 percentage points, and decreases the probability of being inactive by 1.7 percentage points. This result is easily explained if the adult wage rate is considered as a proxy for children's opportunity cost of spending their time at school. Having an agricultural center affects negatively the probability of a child working and attending school by 4.4 percentage points, and it increases his/her probability of being inactive by 7.1 percentage points. Although the intensive use of chemicals in agriculture may be interpreted as a proxy of technological progress in the community, surprisingly it does not 
affect working and schooling choices. Finally, having tractors discourages inactivity by 2.5 percentage points.

Area dummies coefficients show that living away from urban areas decreases the probability that children attend school on a full-time basis. In general, these effects are stronger in Rural Coastal area than in Rural Savannah, likely because agricultural opportunities are more limited and weather dependent in rural Savannah as opposed to Rural Coastal.

Finally, the coefficients of correlation between the errors of the two equations in both models as reported in Table A2 are both negative and strongly significant, indicating a trade-off between the unobservable components of the household decisions concerning primary-school-aged child(ren) employment and school attendance, where these two activities seem to compete with each others.

As mentioned above, the effect of availability of school and distance to school might be different for boys and girls, especially because in developing countries households still tend to give more importance to the education of their sons. In Table 3, we report the effects of

Table 3. Marginal effects of the bivariate probit estimates of children working and attending school by gender

\begin{tabular}{|c|c|c|c|c|}
\hline & $\begin{array}{c}\text { Work \& } \\
\text { school }\end{array}$ & $\begin{array}{l}\text { Work } \\
\text { only }\end{array}$ & $\begin{array}{c}\text { School } \\
\text { only }\end{array}$ & $\begin{array}{c}\text { No work \& } \\
\text { no school }\end{array}$ \\
\hline \multicolumn{5}{|l|}{ Panel A: Model I } \\
\hline \multicolumn{5}{|l|}{ Female } \\
\hline Presence of primary school & 0.034 & $-0.021 * *$ & $0.086^{* * *}$ & $-0.099 * * *$ \\
\hline Presence of middle school & 0.008 & $-0.019 * *$ & $0.064 * * *$ & $-0.053 * * *$ \\
\hline Presence of secondary school & -0.007 & 0.000 & -0.001 & 0.008 \\
\hline \multicolumn{5}{|l|}{ Male } \\
\hline Presence of primary school & 0.028 & -0.001 & 0.005 & -0.032 \\
\hline Presence of middle school & 0.003 & $-0.018^{* * *}$ & $0.060 * *$ & $-0.045^{* * *}$ \\
\hline Presence of secondary school & $-0.040 *$ & $-0.015^{*}$ & 0.055 & 0.001 \\
\hline \multicolumn{5}{|l|}{ Panel B: Model II } \\
\hline \multicolumn{5}{|l|}{ Female } \\
\hline Distance to primary school & $0.002 * *$ & $0.001 * * *$ & $-0.003^{* * *}$ & 0.001 \\
\hline Distance to middle school & $-0.003 *$ & 0.000 & 0.000 & $0.003 * *$ \\
\hline Presence of primary school & 0.034 & $-0.019 *$ & $0.079 * *$ & $-0.095 * * *$ \\
\hline Presence of middle school & 0.010 & $-0.019 * *$ & $0.065^{* *}$ & $-0.056^{* * *}$ \\
\hline Presence of secondary school & -0.007 & 0.000 & -0.002 & 0.008 \\
\hline \multicolumn{5}{|l|}{ Male } \\
\hline Distance to primary school & $0.003 * * *$ & $0.002 * * *$ & $-0.006^{* * *}$ & 0.001 \\
\hline Distance to middle school & $-0.003 * *$ & $-0.002^{* *}$ & $0.007 * * *$ & -0.001 \\
\hline Presence of primary school & 0.029 & 0.000 & 0.002 & -0.031 \\
\hline Presence of middle school & 0.004 & $-0.017 * *$ & $0.058^{* *}$ & $-0.045^{* * *}$ \\
\hline Presence of secondary school & $-0.041^{*}$ & $-0.015^{*}$ & $0.058^{*}$ & -0.001 \\
\hline
\end{tabular}

Notes: The other covariates include: average community school expenditure, child's age, dummies for the number of siblings in different age cells (0-6, 7-12, and 13-17), number of adults in the households by sex and different age cells, presence of parents in the household and their level of education, religion, and per capita expenditure in logarithm, dwelling variables (drink water, electricity, toilet, cement walls in the house, value of livestock), community variables (daily man wage, dummy for having a motorable road, public transport, having an agricultural extension centre, rice husking, having tractors, an agricultural extension officer, a cooperative, using chemical fertilizer or insecticides, a pipe-borne water), and area fixed effects. Partial derivatives for continuous variables are evaluated at their sample means, whereas dummy variables are evaluated for a change from zero to one. Standard errors are clustered by communities. Symbols: *** significant at 1 per cent; ** significant at 5 per cent; $*$ significant at 10 per cent. 
schooling costs (both availability of school and distance to school) on the probability of children attending school and working for boys and girls separately. In Panel A, we only control for the presence of schools of any type on children's time allocation and some differences across gender are already evident. Although the presence of primary school does have no effect on boys' working and schooling choices, it encourages female school attendance and discourages the odds of working full-time or being idle at home. The presence of middle school instead exerts a similar effect on boys and girls. Moreover, the presence of secondary school has some impact on boys' choices, even if weakly significant, but no impact on girls' ones. In Panel B, we add the time distance variables and the differences between boys and girls become even more striking. The distance to middle school has a positive effect on school attendance and a negative effect on working, but this is so only for boys. In general, the school costs variables have an impact on the probability of being idle at home for girls (positive for the distance to middle school and negative for the presence of primary and middle schools), but no effect is found for boys except for the presence of middle school ( -4.5 percentage points). These results suggest that households are encouraged to plan a long-term investment in education for their male kids when the costs for higher education (above primary) are reduced, whereas for girls what matters is only to provide a basic education at the primaryschool level.

\subsection{The working, schooling, and household chores decisions}

So far we have considered only children's economic activity. However, as mentioned above, in developing countries an important part of children's work is represented by household chores. In order to analyse the effect of schooling costs on children's work, school attendance, and household chores activities, we estimate equations [1], [2], and [3] simultaneously through a multivariate probit model. In Table 4 we report the coefficients and the marginal effect in square brackets of the school availability variables (in Model I) and the travel distance variables (in Model II) on children's time allocation (work, schooling, and household chores activities), while controlling for all the covariates listed in Table A1.

Model I in Table 4 shows that the availability of primary school increases the probability of a child attending school by 7.8 percentage points and it decreases the probability of performing household chores by 7.4 percentage points, whereas the effect on the working decision is not statistically significant. Therefore there is some evidence of substitutability only between schooling and household chores. Instead, a middle school in the village increases the probability of a child attending school by 7.0 percentage points, but it does affect neither working nor household chores activities.

Looking at Model II in Table 4 where the travel distances to schools are considered, it turns out that the effect of the travel distance variables on children's work in the labor market and in household chores is positive and significant. In particular, 10 additional minutes of travel time to primary school increase the child probability of working by 0.4 percentage points. On the contrary, school attendance probability decreases by 0.2 percentage points. Therefore, distance to school exerts a conflicting effect on children's time allocation because a higher distance to school seems to force households to choose between children working and studying. Instead, the distance to middle school (in 10 minutes) has an opposite effect on children's working and doing household chores activities; it is positive for household chores $(0.4$ percentage points) and negative for working ( -0.4 percentage points). Finally, as found in Model I, the presence of schools of any type (primary, middle, and secondary) has no effect on children's work but the presence of primary school discourages children's household chores by 


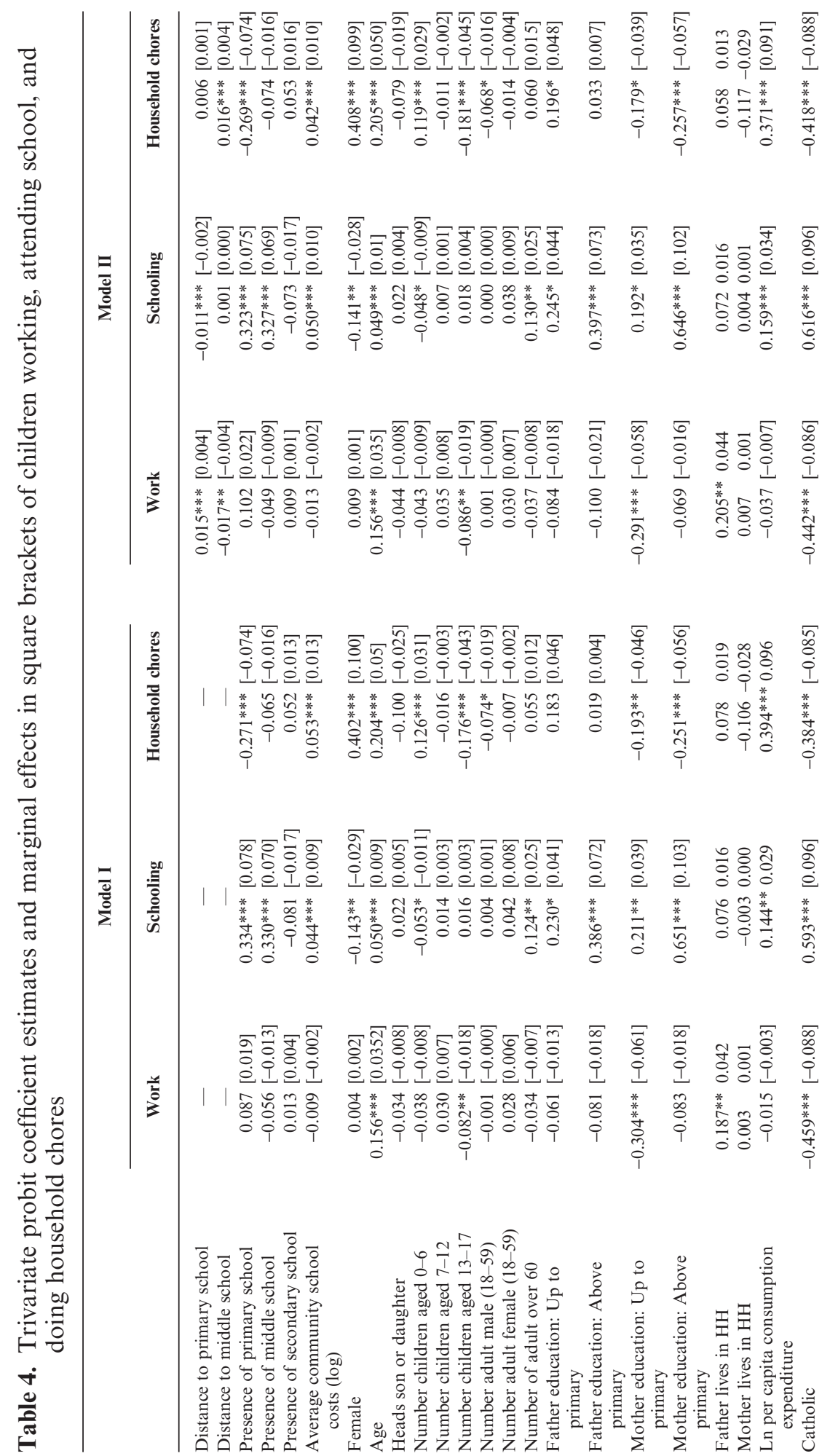




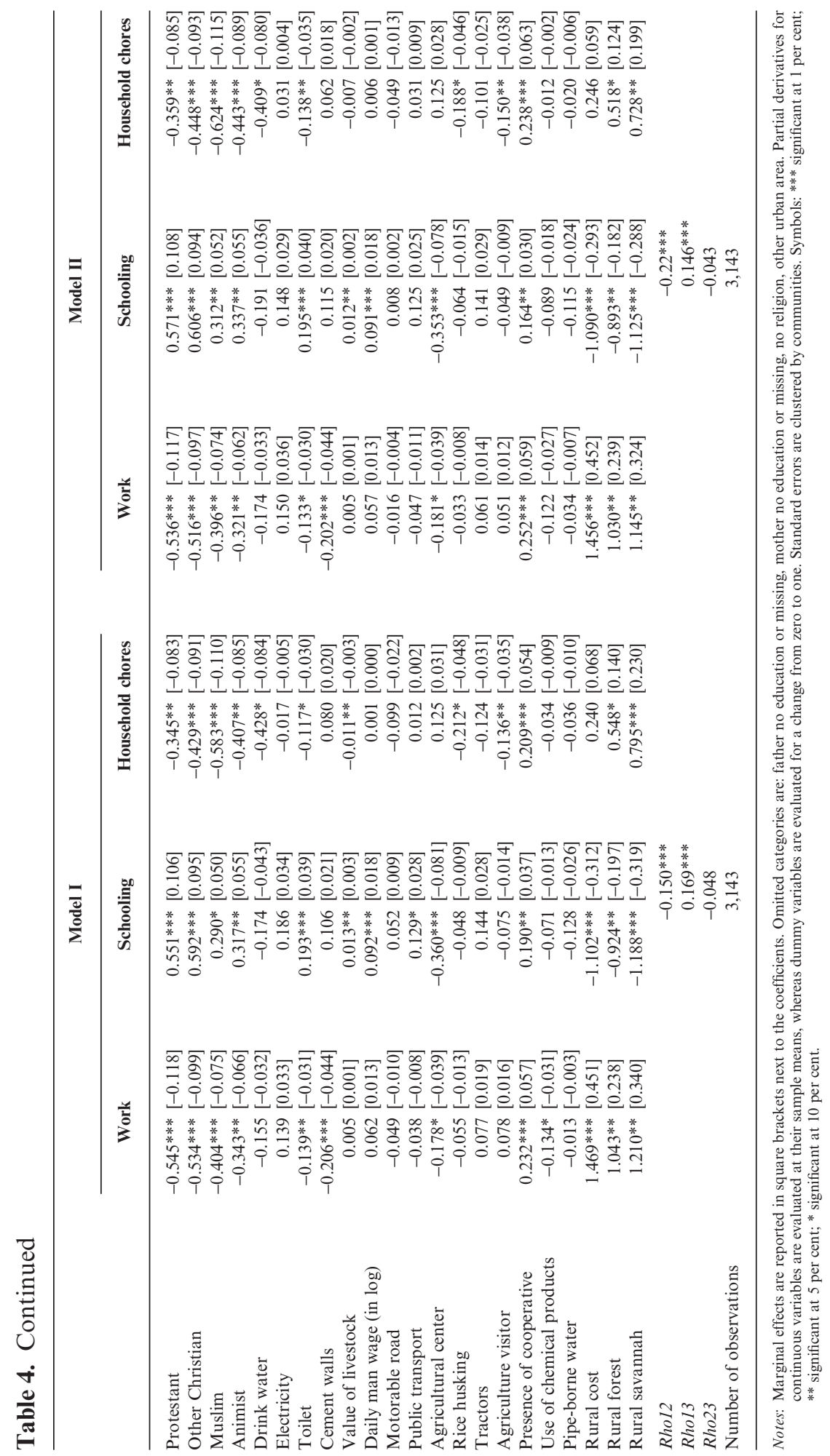


7.4 percentage points. The effect of the availability of schools (both primary and middle) on children school attendance is still positive (7.5 percentage points for primary school and 6.9 percentage points for middle school). However, the magnitude of the availability of school effect is much larger than the travel distance effect. In other words, our results suggest that what matters most for households decisions is the availability of schools in the community rather than the travel distance to schools.

Concerning the other covariates in Model II, the average community school cost encourages school attendance and involvement in household chores. As expected female are 9.9 percentage points more likely to perform household chores, and 2.8 percentage points less likely to attend school. When there are younger siblings aged $0-6$, children are 2.9 percentage points more likely to do houseworks (which include child care), probably because they take care of younger siblings, and 0.9 percentage points less likely to attend school. In a symmetric way, having older siblings aged 13-17 decreases the probability that a child does household chores by 4.5 percentage points and that she/he works by 1.9 percentage points. Interestingly, the higher the mothers educational level, the lower the probability that a child specializes in household chores, whereas having a father with more than primary-school diploma increases the probability of attending school by 7.3 percentage points. As expected, parental education encourages children investment in schooling and discourages children working.

Surprisingly, an increase in per capita expenditure increases children's probability of specializing in houseworks by 9.1 percentage points and it is not easy to provide an explanation for this result, but it also increases children's probability of attending school by 3.4 percentage points. Religion (of any groups) discourages children from doing household chores and working, but it increases the probability of attending school. The wealth proxy variables have a negative effect on children's probability to be engaged in housework activity (having drink water and a toilet in the dwelling reduces the children probability of performing household chores by 8.0 percentage points and 3.5 percentage points, respectively), whereas having a toilet has a positive effect on the probability of attending school and a negative one on the probability of working. Also having cement walls reduces the odds of working. Very few community variables have a significant effect on children's time allocation. Only having an agricultural visitor and a rice husking affect negatively by 3.8 and 4.6 percentage points the probability of a child of performing houseworks. The presence of a cooperative (agricultural center) increases (decreases) child work and schooling attendance.

Finally, children living in rural areas are more likely to work or to do household chores and less likely to attend school. These effects are largely expected as these areas have few infrastructures and facilities that make children more likely to be employed in any type of work.

When looking at the coefficients of correlation among the working, school attendance, and household chores equations at the bottom of Table 4, we see that the unobservables of the schooling and work decisions are negatively correlated, whereas the error term of the working equation is positively correlated with the one of the household chores equation. On the contrary, the error terms of the schooling and household chore equations are not correlated. In other words, in terms of unobservable factors, a child who is more likely to work is also more likely to perform household chores, but only working in economic activity seems to be in conflict with formal education.

Overall our results convey the message that the reduction in schooling costs have a certain degree of success in discouraging both children's work and involvement in household chores 
Table 5. Trivariate probit coefficient estimates and marginal effects in square brackets of the probability of children working, attending school, and doing household chores by gender

\begin{tabular}{lccr}
\hline & Work & Schooling & Household chores \\
\hline Female & & & \\
Distance to primary school & $0.012^{* * *}[0.003]$ & $-0.010^{* *}[-0.002]$ & $0.004[0.001]$ \\
Distance to middle school & $-0.015^{*}[-0.003]$ & $-0.010[-0.002]$ & $0.021^{* * *}[0.006]$ \\
Presence of primary school & $0.002[-0.001]$ & $0.439^{* * *}[0.109]$ & $-0.366^{* * *}[-0.117]$ \\
Presence of middle school & $0.039[0.009]$ & $0.356^{* * *}[0.080]$ & $0.009[0.004]$ \\
Presence of secondary school & $-0.013[-0.003]$ & $-0.020[-0.004]$ & $-0.029[-0.010]$ \\
Male & & & \\
Distance to primary school & $0.023^{* * *}[0.005]$ & $-0.014^{* *}[-0.002]$ & $0.010^{*}[0.001]$ \\
Distance to middle school & $-0.029^{* * *}[-0.006]$ & $0.018[0.003]$ & $0.014^{*}[0.003]$ \\
Presence of primary school & $0.028[0.006]$ & $0.194[0.039]$ & $0.020[0.004]$ \\
Presence of middle school & $0.080[0.018]$ & $0.269^{* *}[0.052]$ & $-0.345^{* * *}[-0.070]$ \\
Presence of secondary school & $-0.304^{*}[-0.060]$ & $0.101[0.018]$ & $-0.006[-0.001]$ \\
\hline
\end{tabular}

Notes: Marginal effects are reported in square brackets next to the coefficients. The other covariates include: average community school expenditure, child's age, dummies for the number of siblings in different age cells $(0-6$, 7-12, and 13-17), number of adults in the households by sex and different age cells, presence of parents in the household and their level of education, religion, and per capita expenditure in logarithm, dwelling variables (drink water, electricity, toilet, cement walls in the house, value of livestock), community variables (daily man wage, dummy for having a motorable road, public transport, having an agricultural extension centre, rice husking, having tractors, an agricultural extension officer, a cooperative, using chemical fertilizer or insecticides, a pipe-borne water), and area fixed effects. Partial derivatives for continuous variables are evaluated at their sample means, whereas dummy variables are evaluated for a change from zero to one. Standard errors are clustered by communities. Symbols: ${ }^{* * *}$ significant at 1 per cent; ${ }^{* *}$ significant at 5 per cent; ${ }^{*}$ significant at 10 per cent.

and in enforcing children's school attendance in Ghana, with an effect being much stronger for the increase in the availability of school than for the reduction in travel time distance to school.

As boys and girls are differently involved in household chores activities, we investigate in a regression analysis whether there are systematic differences across gender concerning the effect of availability of school and distance to schools on children's time allocation (Table 5). For girls the travel distance to primary school has a significant and positive impact on the probability of working and at the same time it significantly discourages school attendance. Interestingly, the distance to middle school has no effect on schooling, but it has a negative effect on working (even if weakly significant) and a positive one on household works. When looking at the availability of schools, we see that both the presence of primary school and the presence of middle school encourage investment in schooling (10.9 and 8.0 percentage points, respectively) but only the presence of primary school discourages time spent in household chores ( -11.7 percentage points).

The results for boys are substantially different. Among the most striking differences, we can see that the distance to middle school significantly reduces children probability of working and only weakly increases the probability of performing household chores. The presence of elementary school does exert no effect on boys' time use, whereas the availability of middle schools increases the probability of boys attending school by 5.2 percentage points, and decreases household chores activities probability by 7.0 percentage points. Interestingly, also the presence of secondary school matters for boys' probability of working, decreasing it by 6.0 percentage points. 
These results suggest that the distance to schools (both primary and middle) has a similar impact on girls and boys, whereas the availability of primary schools matters only for girls. Moreover, there is a clear substitution effect for girls among schooling and household chores when primary school is present in the community, whereas the substitution effect is at work for boys only when the middle school is available.

Overall these results suggest that when boys have access to the most remunerative type of schools (above primary), parents have some incentive to send their sons to school and to discourage their involvement in household chores or market work. Girls instead tend to be more (less) involved in household chores (market work) when middle school is far. For girls the presence of primary school is very important, whereas for boys it does not matter. Gender difference in the returns to schooling, social, cultural, and religious norms or simply parental preferences may be advocated to explain the sex-based differences in households' choices about their children's time allocation. ${ }^{21}$ This result implies that girls may be differently responsive to policy measures addressing the issues of children time allocation, and points to the need for different policy approaches for reducing girls' and boys' work and household chores activities and for increasing their school attendance.

\section{Robustness checks}

The estimates presented so far show that in Ghana the distance to primary school discourages children's school attendance and makes them more likely to work. Interestingly, the distance to middle school has a negative effect on work decision and a positive one on household chores activities. This result could be due to the fact that having a middle school nearby increases the likelihood that parents invest in their children's full-time education, and education is perceived as incompatible with work activities but not with household chores. Moreover, the availability of both primary and middle schools has a positive effect on schooling decisions. However, there are two potential sources of bias that could affect our estimates.

The first problem we have to deal with is the potential endogeneity of household per capita expenditure, as mentioned in Section 4. The instruments used to identify per capita expenditure are community mean per capita expenditures, household head characteristics, household composition variables, acres of land owned by the household, value of agricultural business assets, income from remittances and other unearned income (Glewwe and Jacoby, 1994; Lavy, 1996). Following Glewwe and Jacoby (1994), we first regress log per capita expenditures on this set of instruments and then include the residuals from this stage along with actual log per capita expenditures in the trivariate probit model. From Table 6 it turns out that the coefficients on the residuals in the schooling and household chores equations are significant, suggesting that the consumption expenditures might be actually endogenous; therefore we need to control for them in our estimates (Smith and Blundell, 1986). Notwithstanding, the results are not sensitive to this procedure and the coefficients of interest on the travel distance variables and the availability of schools hardly change.

The second problem is that using travel distances to proxy the costs of education may create a problem of endogeneity if schools are not randomly allocated over the country. This problem could arise if households with a greater preference for schooling are more able to move towards areas with better provision of schools. Moreover, in many poor countries, allocation of infrastructures like schools and health services might be determined by local demand. In both cases, estimations that do not take into account the non-random 
Table 6. Trivariate probit coefficient estimates and marginal effects in square brackets of the probability of children working, attending school, and doing household chores correcting for the endogeneity of expenditure

\begin{tabular}{lrrr}
\hline & Work & Schooling & Household chores \\
\hline Distance to primary school & $0.015^{* * *}[0.003]$ & $-0.011^{* * *}[-0.002]$ & $0.006^{*}[0.001]$ \\
Distance to middle school & $-0.018^{* * *}[-0.004]$ & $0.001[0.000]$ & $0.016^{* * *}[0.004]$ \\
Presence of primary school & $0.117[0.025]$ & $0.304^{* * *}[0.069]$ & $-0.249^{* * *}[-0.068]$ \\
Presence of middle school & $-0.043[-0.010]$ & $0.320^{* * *}[0.067]$ & $-0.069[-0.016]$ \\
Presence of secondary school & $0.023[0.006]$ & $-0.087[-0.016]$ & $0.073[0.018]$ \\
Ln per capita expenditure & $0.311^{* *}[-0.071]$ & $-0.241[0.074]$ & $0.238^{*}[0.043]$ \\
Ln per capita expend. residuals & $-0.011[0.069]$ & $0.047^{* * *}[-0.046]$ & $0.044^{* * *}[0.056]$ \\
Rho12 & & $-0.186^{* * *}$ & \\
Rho13 & & $0.183^{* * *}$ & \\
Rho23 & & -0.014 & \\
Number of observations & & 3,143 & \\
\hline
\end{tabular}

Notes: Marginal effects are reported in square brackets next to the coefficients. For the list of the other covariates used see notes to Table 5. The per capita expenditure has been instrumented using as instrument community mean per capita expenditures, household head characteristics, household composition variables, acres of land owned by the household, value of agricultural business assets, income from remittances and other unearned income. Standard errors are bootstrapped in order to take into account of the generated variable and clustered by communities. Partial derivatives for continuous variables are evaluated at their sample means, whereas dummy variables are evaluated for a change from zero to one. Symbols: *** significant at 1 per cent; ** significant at 5 per cent; * significant at 10 per cent.

location of schools will yield inconsistent estimates of the impact of school characteristics on household choices. In the context of rural Ghana the location of primary schools can be considered exogenous as the government policy is to place a primary school in each community. Additionally, secondary schools are mainly concentrated in large towns or rural centers, and it is very unlikely that a rural community may attract a secondary school (Lavy, 1996). Therefore, the endogeneity problem should arise only with respect to middle schools.

In order to evaluate the endogenous location of the three types of schools, we regress the availability of primary, middle, and secondary schools on average village characteristics (respectively in columns 2, 3, and 4 of Table 7). As covariates, we include the presence of a motorable road passing by the community and its distance to the village in kilometers, the presence of electricity, pipe-borne water, post office, public transport, rice husking, tractors, a cooperative, an agent visiting the farmers, and finally the use of chemical substances by farmers. It turns out that almost none of these village characteristics have a statistically significant effect on the probability of having a primary school in the village except for the presence of public transport and a pipe-borne water (column 2). On the contrary, the presence of electricity, pipe-borne water, post office, public transport, a cooperative, and use of chemical products increases the probability of having a middle school in the community (column 3 ). Finally, the presence of electricity and pipe-borne water increases the probability of having a secondary school in the community; however, this last result should be interpreted with caution as the effect on the secondary school location could not be estimated for some covariates. Overall these results suggest that the endogeneity should not be a problem for primary and secondary schools; on the contrary, some village-level variables, which can be considered as a proxy of 'modernity', are positively related to the presence of middle schools in the community. 
Table 7. Coefficient estimates and marginal effects in square brackets of community variables on the presence of schools in the community

\begin{tabular}{lccr}
\hline & Primary school & Middle school & Secondary school \\
\hline Motorable road & $0.185[0.130]$ & $0.425[0.217]$ & - \\
Distance from motorable road & $0.043[0.009]$ & $-0.002[-0.001]$ & - \\
Electricity & $0.006[0.001]$ & $0.753^{* *}[0.267]$ & $1.530^{* * *}[0.089]$ \\
Pipe-borne water & $0.936^{*}[0.169]$ & $1.003^{*}[0.339]$ & $0.820^{* *}[0.048]$ \\
Public transport & $0.645^{* *}[0.033]$ & $0.637^{* *}[0.201]$ & $0.51[0.030]$ \\
Post-office & - & $1.265^{* *}[0.432]$ & - \\
Rice husking & $0.319[0.004]$ & $0.077[0.056]$ & $0.138[0.009]$ \\
Tractors & $0.925^{*}[0.058]$ & $0.146[0.048]$ & $0.145[0.009]$ \\
Agriculture visitor & $0.326[0.067]$ & $0.148[0.044]$ & $0.556[0.031]$ \\
Presence of cooperative & $0.449[0.069]$ & $0.664^{* * *}[0.213]$ & $-0.211[-0.011]$ \\
Use of chemical products & $0.353[0.011]$ & $0.483^{* *}[0.133]$ & $0.723^{*}[0.032]$ \\
Number of observations & 223 & 223 & 223 \\
Pseudo $R^{2}$ & 0.175 & 0.319 & 0.389 \\
\hline
\end{tabular}

Notes: Marginal effects are reported in square brackets next to the coefficients. Symbols: *** significant at 1 per cent; ** significant at 5 per cent; * significant at 10 per cent.

We use the previous results to perform an instrumental variable estimation. In particular, we instrument the access to middle school using as exclusion restrictions the six village characteristics that we have proved to be correlated with middle school location but that should not be correlated with work, school, and housework decisions. ${ }^{22}$ We estimate a simultaneous multivariate probit model that analyses the joint decisions of a household concerning children's work, school attendance, and household chores activities and of living in a community with middle school. As expected, the instruments reported in column 5 of Table 8 turn out to be strongly significant. Table 8 shows that the results are not qualitatively different from those reported in Table 4 and the main conclusions drawn in the previous section still hold.

\section{Conclusions}

The issue of child labor has received a lot of attention in recent years. Although much has been done in terms of child work reduction in the last century, the number of children working is still substantial, representing a source of serious concern for government. Strategies aimed at reducing or eliminating child labor need the identification of its determinants in order to be effective.

This paper presents a study of the impact of travel distance to school and availability of schools on children's time allocation, using the GLSS 1998-99 for Ghana. The significant contribution of this paper lies in integrating the household decisions concerning primaryschool-aged children's schooling, work, and household chores activities, and studying the simultaneous effect of the above mentioned school costs variables on the households' choices. The estimates of the multivariate probit model show that the distance to primary school discourages children's school attendance and makes them more likely to work. Interestingly, the distance to middle school discourages children's work and boosts 
Table 8. Multivariate probit coefficient estimates and marginal effects in square brackets of the probability of children working, attending school, and doing household chores correcting for the endogeneity of middle school placement

\begin{tabular}{|c|c|c|c|c|}
\hline & Work & Schooling & Household chores & Middle school \\
\hline $\begin{array}{l}\text { Distance to primary } \\
\text { school }\end{array}$ & $0.014 * * *[0.003]$ & $-0.011 * * *[-0.002]$ & $0.005[0.001]$ & - \\
\hline $\begin{array}{l}\text { Distance to middle } \\
\text { school }\end{array}$ & $-0.018^{* * *}[-0.004]$ & $0.001[0.002]$ & $0.016^{* * *}[0.004]$ & - \\
\hline $\begin{array}{l}\text { Presence of primary } \\
\text { school }\end{array}$ & $0.144[0.030]$ & $0.301 * * *[0.069]$ & $-0.272 * * *[-0.074]$ & - \\
\hline $\begin{array}{l}\text { Presence of middle } \\
\text { school }\end{array}$ & $-0.182[-0.036]$ & $0.219 *[0.035]$ & $-0.065[-0.020]$ & - \\
\hline $\begin{array}{l}\text { Presence of secondary } \\
\text { school }\end{array}$ & $0.020[0.006]$ & $-0.092[-0.021]$ & $0.052[0.014]$ & - \\
\hline Electricity in community & - & - & - & $0.869^{* * *}[0.218]$ \\
\hline Pipe-borne water & - & - & - & $1.417 * * *[0.272]$ \\
\hline Public transport & - & - & - & $0.469 * * *[0.143]$ \\
\hline Telephone/postal office & - & - & - & $0.948 * * *[0.205]$ \\
\hline Presence of cooperative & - & - & - & $0.292 * * *[0.081]$ \\
\hline Use of chemical products & - & - & - & $0.468 * * *[0.151]$ \\
\hline Rhol2 & \multicolumn{4}{|c|}{$-0.204 * * *$} \\
\hline Rhol3 & \multicolumn{4}{|c|}{$0.190 * * *$} \\
\hline Rhol4 & \multicolumn{4}{|c|}{0.083} \\
\hline Rho23 & \multicolumn{4}{|c|}{-0.038} \\
\hline Rho24 & \multicolumn{4}{|c|}{0.072} \\
\hline Rho34 & \multicolumn{4}{|c|}{0.022} \\
\hline Number of observations & \multicolumn{4}{|c|}{3,143} \\
\hline
\end{tabular}

Notes: Marginal effects are reported in square brackets next to the coefficients. For the list of the other covariates used see notes to Table 5. Partial derivatives for continuous variables are evaluated at their sample means, whereas dummy variables are evaluated for a change from zero to one. Partial derivatives for continuous variables are evaluated at their sample means, whereas dummy variables are evaluated for a change from zero to one. Symbols: *** significant at 1 per cent; ** significant at 5 per cent; ${ }^{*}$ significant at 10 per cent.

household chores activities. It could be due to the fact that working is perceived by parents as incompatible with schooling, whereas household chores could instead be still compatible with school attendance or at least not interfere with it. Moreover, the availability of both primary and middle schools has a positive effect on schooling decisions, and having a primary school nearby also discourages household chores activity. The results do not change significantly after controlling for the endogeneity of household expenditures and for the endogeneity of middle school location. When looking at the magnitude of the effects, it turns out that availability of schools exerts a larger influence on children's time use rather than the travel distance to schools. This result implies that policy should be targeted to improving access to school by providing schools in each community rather than creating, for example, a more efficient transportation system to reach schools (buses, roads, trains, etc.). We also find that household decisions about children's time use differ by children's sex, suggesting that girls may be differently responsive to policy measures aimed at reducing work and household chores activities and at increasing their school attendance. 


\section{Appendix}

Table A1. Summary statistics

\begin{tabular}{|c|c|c|}
\hline & Mean & Standard deviation \\
\hline Work only & 0.05 & 0.21 \\
\hline Study only & 0.71 & 0.45 \\
\hline Work and study & 0.12 & 0.33 \\
\hline Neither work nor study & 0.12 & 0.32 \\
\hline School attendance & 0.83 & 0.38 \\
\hline Work & 0.17 & 0.37 \\
\hline Household chores & 0.20 & 0.40 \\
\hline Distance to primary school* & 4.36 & 8.66 \\
\hline Distance to middle school* & 4.38 & 5.82 \\
\hline Presence of primary school & 0.87 & 0.34 \\
\hline Presence of middle school & 0.62 & 0.48 \\
\hline Presence of secondary school & 0.11 & 0.32 \\
\hline Average community school costs (log) & 9.81 & 2.49 \\
\hline \multicolumn{3}{|l|}{ Child characteristics } \\
\hline Female & 0.49 & 0.50 \\
\hline Age & 9.49 & 1.71 \\
\hline Head's son or daughter & 0.76 & 0.43 \\
\hline \multicolumn{3}{|l|}{ Household characteristics } \\
\hline Number children aged $0-6$ & 1.26 & 1.15 \\
\hline Number children aged 7-12 & 1.07 & 0.97 \\
\hline Number children aged $13-17$ & 0.83 & 0.92 \\
\hline Number adult male (18-59) & 0.99 & 0.88 \\
\hline Number adult female (18-59) & 1.28 & 0.78 \\
\hline Number of adult over 60 & 0.34 & 0.58 \\
\hline Ln per capita consumption expenditure & 13.13 & 0.61 \\
\hline \multicolumn{3}{|l|}{ Religion: } \\
\hline Catholic & 0.18 & 0.38 \\
\hline Protestant & 0.42 & 0.49 \\
\hline Other Christian & 0.18 & 0.38 \\
\hline Muslim & 0.09 & 0.29 \\
\hline Animist & 0.09 & 0.29 \\
\hline No religion & 0.04 & 0.19 \\
\hline \multicolumn{3}{|l|}{ Parent characteristics } \\
\hline \multicolumn{3}{|l|}{ Father education } \\
\hline None & 0.61 & 0.49 \\
\hline Up to primary & 0.07 & 0.25 \\
\hline Above primary & 0.32 & 0.47 \\
\hline \multicolumn{3}{|l|}{ Mother education } \\
\hline None & 0.68 & 0.47 \\
\hline Up to primary & 0.13 & 0.34 \\
\hline Above primary & 0.19 & 0.40 \\
\hline Father lives in $\mathrm{HH}$ & 0.60 & 0.49 \\
\hline Mother lives in $\mathrm{HH}$ & 0.75 & 0.43 \\
\hline \multicolumn{3}{|l|}{ Dwelling variables } \\
\hline Drink water & 0.02 & 0.15 \\
\hline Electricity & 0.15 & 0.36 \\
\hline Toilet & 0.51 & 0.50 \\
\hline Cement walls & 0.27 & 0.44 \\
\hline Value of livestocks & 7.88 & 6.17 \\
\hline
\end{tabular}


Table A1. Continued

Mean

Standard deviation

\section{Community variables}

Daily man wage (in log)

$\begin{array}{cc}9.16 & 1.11 \\ 0.86 & 0.35 \\ 0.67 & 0.47 \\ 0.18 & 0.39 \\ 0.08 & 0.27 \\ 0.17 & 0.38 \\ 0.60 & 0.49 \\ 0.32 & 0.47 \\ 0.78 & 0.41 \\ 0.18 & 0.39 \\ 0.3 & 0.46 \\ 0.15 & 0.35\end{array}$

Motorable road

Public transport

Agricultural center

Rice husking

Tractors

Agriculture visitor

Presence of cooperative

Use of chemical products

Pipe-borne water

Electricity

Telephone/post office

0.15

0.35

\section{Area variables}

Urban area

0.03

0.14

Rural cost

0.21

0.41

Rural forest

0.49

0.50

Rural savannah

0.28

0.45

Number of observations

3,143

Note: * In 10 minutes.

Table A2. Bivariate probit estimates of the probability of children working and attending school

\begin{tabular}{|c|c|c|c|c|}
\hline & \multicolumn{2}{|c|}{ Model I } & \multicolumn{2}{|c|}{ Model II } \\
\hline & Work & Schooling & Work & Schooling \\
\hline Distance to primary school & - & - & $0.015^{* * *}$ & $-0.011 * * *$ \\
\hline Distance to middle school & - & - & $-0.017 * *$ & 0.001 \\
\hline Presence of primary school & 0.093 & $0.337 * * *$ & 0.109 & $0.316^{* * *}$ \\
\hline Presence of middle school & -0.061 & $0.328^{* * *}$ & -0.053 & $0.325^{* * *}$ \\
\hline Presence of secondary school & 0.015 & -0.086 & 0.009 & -0.083 \\
\hline Average community school costs & -0.009 & $0.044 * * *$ & -0.012 & $0.049 * * *$ \\
\hline Female & 0.009 & $-0.139^{* *}$ & 0.010 & $-0.142 * *$ \\
\hline Age & $0.157 * * *$ & $0.049 * * *$ & $0.157 * * *$ & $0.049 * * *$ \\
\hline Head's son or daughter & -0.040 & 0.016 & -0.050 & 0.019 \\
\hline Number children aged $0-6$ & -0.037 & $-0.052^{*}$ & -0.042 & $-0.047^{*}$ \\
\hline Number children aged 7-12 & 0.031 & 0.015 & 0.036 & 0.007 \\
\hline Number children aged 13-17 & $-0.081 * *$ & 0.015 & $-0.084 * *$ & 0.017 \\
\hline Number adult male $(18-59)$ & -0.000 & 0.006 & 0.001 & 0.002 \\
\hline Number adult female (18-59) & 0.025 & 0.039 & 0.029 & 0.040 \\
\hline Number of adult over 60 & -0.036 & $0.129 * *$ & -0.038 & $0.128 * *$ \\
\hline Father education: Up to primary & -0.057 & $0.227 *$ & -0.084 & $0.245^{*}$ \\
\hline Father education: Above primary & -0.085 & $0.386^{* * *}$ & -0.102 & $0.392 * * *$ \\
\hline Mother education: Up to primary & $-0.311^{* * *}$ & $0.216^{* *}$ & $-0.292^{* * *}$ & $0.193^{*}$ \\
\hline Mother education: Above primary & -0.082 & $0.653 * * *$ & -0.068 & $0.648 * * *$ \\
\hline Father lives in $\mathrm{HH}$ & $0.188^{* *}$ & 0.079 & $0.203 * *$ & 0.077 \\
\hline Mother lives in $\mathrm{HH}$ & 0.004 & 0.004 & 0.010 & 0.004 \\
\hline Ln per capita consumption expenditure & -0.015 & $0.146^{* *}$ & -0.037 & $0.167 * * *$ \\
\hline Catholic & $-0.453 * * *$ & $0.599 * * *$ & $-0.445^{* * *}$ & $0.610^{* * *}$ \\
\hline
\end{tabular}


Table A2. Continued

\begin{tabular}{|c|c|c|c|c|}
\hline & \multicolumn{2}{|c|}{ Model I } & \multicolumn{2}{|c|}{ Model II } \\
\hline & Work & Schooling & Work & Schooling \\
\hline Protestant & $-0.538 * * *$ & $0.552 * * *$ & $-0.539 * * *$ & $0.566 * * *$ \\
\hline Other Christian & $-0.516^{* * *}$ & $0.589^{* * *}$ & $-0.511 * * *$ & $0.598 * * *$ \\
\hline Muslim & $-0.392 * *$ & $0.289^{*}$ & $-0.396^{* *}$ & $0.307 * *$ \\
\hline Animist & $-0.332 * *$ & $0.325^{* *}$ & $-0.319^{* *}$ & $0.334 * *$ \\
\hline Drink water & -0.169 & -0.165 & -0.179 & -0.183 \\
\hline Electricity & 0.139 & 0.176 & 0.148 & 0.154 \\
\hline Toilet & $-0.142 * *$ & $0.194 * * *$ & $-0.138^{* *}$ & $0.199 * * *$ \\
\hline Cement walls & $-0.201 * * *$ & 0.110 & $-0.197 * * *$ & 0.110 \\
\hline Value of livestock & 0.005 & $0.013^{* *}$ & 0.005 & $0.012^{* *}$ \\
\hline Daily man wage (in log) & 0.060 & $0.091 * * *$ & 0.057 & $0.091 * * *$ \\
\hline Motorable road & -0.052 & 0.047 & -0.018 & 0.011 \\
\hline Public transport & -0.039 & $0.135^{*}$ & -0.050 & 0.128 \\
\hline Agricultural center & $-0.181^{*}$ & $-0.349 * * *$ & $-0.182^{*}$ & $-0.343 * * *$ \\
\hline Rice husking & -0.044 & -0.052 & -0.022 & -0.080 \\
\hline Tractors & 0.078 & 0.141 & 0.059 & 0.146 \\
\hline Agriculture visitor & 0.078 & -0.073 & 0.050 & -0.049 \\
\hline Presence of cooperative & $0.234 * * *$ & $0.187 * *$ & $0.250 * * *$ & $0.164 * *$ \\
\hline Use of chemical products & $-0.137 *$ & -0.065 & -0.123 & -0.087 \\
\hline Pipe-borne water & -0.021 & -0.123 & -0.038 & -0.117 \\
\hline Rural cost & $1.503 * * *$ & $-1.123 * * *$ & $1.499 * * *$ & $-1.119 * * *$ \\
\hline Rural forest & $1.068 * *$ & $-0.945^{* *}$ & $1.062 * *$ & $-0.919 * *$ \\
\hline Rural savannah & $1.238^{* *}$ & $-1.210^{* * *}$ & $1.180 * *$ & $-1.153 * * *$ \\
\hline Constant & $-3.371 * * *$ & $-3.071^{* * *}$ & $-3.060 * * *$ & $-3.317 * * *$ \\
\hline Rhol2 & \multicolumn{2}{|c|}{$-0.239 * * *$} & \multicolumn{2}{|c|}{$-0.229 * * *$} \\
\hline Number of observations & \multicolumn{2}{|c|}{3,143} & \multicolumn{2}{|c|}{3,143} \\
\hline
\end{tabular}

Notes: Omitted categories are: father no education or missing, mother no education or missing, no religion, other urban area. Standard errors are clustered by communities. Symbols: *** significant at 1 per cent; ${ }^{* *}$ significant at 5 per cent; * significant at 10 per cent.

\section{Notes}

${ }^{1}$ For example, if children enrollment and attendance rates do not depend on local school infrastructure, the construction of new schools will have negligible effect on overall schooling levels and working rates, leading to a waste of resources. In this case, policy-makers should instead direct the marginal efforts to the demand side of the problem.

${ }^{2}$ Despite the fact elementary school is compulsory, the non-school attendance rates in Ghana are very high with wide gender disparities, especially in rural areas (World Bank, 1993). Moreover, there is an inconsistency between minimum age for employment and schooling (common to many countries), which makes the implementation of these laws complicated (ILO, 1996). Ghana's labor Decree (1967) prohibits employment for children under the age of 15 , although the law permits undefined light work by children. The Education Act (1961) states that education is free and compulsory, although it does not define until what age the child should be in school.

${ }^{3}$ In this paper, work is defined in terms of economic activity as derived by the System of National Accounts (SNA, 1993), which sets the international statistical standards for the measurement of the market economy. Economic activity covers all market production (paid work) and some types of non-market production (unpaid work). The economic activity can be pursued in either the formal or informal sector and in either urban or rural areas. The SNA also provides a definition for non-economic activity as any productive activity falling outside the SNA production boundary for measuring the GDP. 
It consists mainly of work activities, usually referred to as household chores, performed for the production of goods and services by the household members for their own consumption, using their own capital and their own unpaid labor (ILO, 2006). For a detailed discussion on the distinction between family and non-family work and economic and non-economic productive activities the reader should refer to UCW (2007).

${ }^{4}$ For a detailed discussion refer to Guarcello et al. (2005a): http://www.ucw-project.org/pdf/ publications/noneconomicactivities2.pdf.

${ }^{5}$ This is an extreme simplification of the scheme followed by the households to make choices about their children's time use. The interested reader can refer to Cigno and Rosati (2005) and to the literature cited therein for a detailed discussion.

${ }^{6}$ The subscript ' $i$ ' refers to the child; however, work $_{i}$ and attend $_{i}$ can be interpreted as the reduced-form parental demand for children market work and schooling, respectively. In other words, they represent parental choices for each child between 7 and 12 years of age present in the household.

${ }^{7}$ Lavy (1996) analyses the correlation between school availability and school enrollment in Ghana in 1987 using community distance variables augmented by information on the quality of primary and middle schools obtained by a follow-up survey in 1988. Unfortunately, the survey currently used in this paper (GLSS 1998) does not provide school quality information.

${ }^{8}$ We could have computed the potential travel distance from secondary school in a similar way, but too few children attend secondary school in our sample and the imputation procedure would have produced a variable heavily affected by measurement error and with small variability.

${ }^{9}$ The GHK simulator belongs to the class of importance sampling simulators where one draws from some distribution other than the considered joint distribution, and then re-weights to obtain an unbiased simulator. In this way the importance sampling can reduce the simulation error by oversampling parts of the error distribution that are most informative. In the case of a multinomial probit model, the main characteristics of the GHK simulator here used are that it splits the joint normal probability density function into a series of conveniently simulated conditional probabilities from a truncated normal distribution, where the joint probability can be written as the product of each of the conditional simulated probabilities coming from the truncated normal.

${ }^{10}$ Imperfect credit markets are one reason why educational choices might depend on household income; moreover, wealthier parents may value education more and this would explain why children from poorer households tend to quit earlier.

${ }^{11}$ The school variables are also available for children aged 5 and 6 , but they are not used because work information is not recorded for children in this age group. We also extend the sample to include children between 7 and 15 years of age, in order to make allowance for late entry and grade repetitions and to test the robustness of our results. The findings of the empirical section are very similar to those obtained with children aged 7-12. Results are available on request from the author.

${ }^{12}$ As mentioned above, the GLSS cover about 26,000 individuals. After deleting observations with missing information on employment and school attendance ( 24 per cent) and selecting only children between 7 and 12 years of age ( 23 per cent) we are left with 4,867 observations. We select only rural households for a total of 3,143 primary-school-aged children, belonging to 1,917 households, which represent the sample of analysis. As largely expected, the sample of children in urban areas dropped from the sample (1,524 observations) shows very different characteristics in terms of employment, school attendance, and household chores activities with respect to the sample of children in rural areas. For instance, the employment rate for urban kids is much lower than for rural kids (6.5 per cent versus 17.0 per cent), the school attendance rate is higher ( 90 per cent versus 83 per cent), and they are less involved in household chores (14.8 per cent versus 20.0 per cent). It implies that students living in rural areas are not representative of all children their age. However, we should take into account that the problem of availability of schools and distance to schools is especially relevant for children living in rural areas, which represents indeed our sample of analysis.

${ }^{13}$ Ideally, we would like to have a variable measuring school intensity; unfortunately the GLSS survey does not provide this information. In order to build the variable attending school, we make use of the question: 1. Did (NAME) attend schoollcollege at any time during the past 12 months?, complemented by 
the two questions: 2. Has (NAME) ever attended school? and 3. Has (NAME) left school now?. Moreover, we identify as not attending school those children who declare that they cannot read letter in English and in Ghanian, cannot write letter in English and in Ghanian, and cannot do written calculations.

${ }^{14}$ We have chosen the threshold of 2 hours because enough children declare to do houseworks for at least 2 hours a day whereas few children do household chores for at least 3 or 4 hours a day.

${ }^{15}$ The school costs variable includes school and registration fees, contribution to parent/teacher associations, uniform and sport clothes, books and school supplies, transportation to and from school, food, board, and lodging at school, other expenses (clubs, extra classes), other in-kind expenses. This question has been asked only to the households sending their kids to school; therefore this variable could be potentially endogenous if for example households who give more value to school and send their kids to school and not to work are also are more willing to afford higher costs. For this reason, we use the average school costs by household's community of residence.

${ }^{16}$ In a less parsimonious specification of the model we have included three variables indicating whether the father is employed in farming activities, in non-farming activities, or not working. However, they never turned out to be either jointly or singularly significant and therefore they were excluded from the analysis. We did not include the same dummies for the mother as they could be endogenous to children's work decisions.

${ }^{17}$ Agricultural extension officers are intermediaries between research (or any other source providing new information) and farmers. They operate as facilitators and communicators helping farmers in their decision making and ensuring that appropriate knowledge is implemented in order to obtain the best results in terms of sustainable production and general rural development.

${ }^{18}$ The coefficient estimates corresponding to the marginal effects of Tables 1 and 2 are reported in Table A2.

${ }^{19}$ Often, middle schools are located in the same building/area as primary schools. In this case, for every middle school we would have the same distance of primary schools. If these variables are closely correlated but have different skewness and kurtosis, this may change signs and significance of the coefficients. However, the correlation between the distance variables to elementary school and middle school in our data is only slightly above 0.5 . Moreover, these two variables have similar skewness and kurtosis. Finally, if we run two separate regressions, one including only the distance to primary school, and the other including only the distance to middle school, the main coefficients of interest (on distance to school and availability of school) hardly change with respect to the full regression (with both time distance variables). The fact that the results are robust to the inclusion or exclusion of some time distance variables suggests that they are not driven by potential collinearity between the distance to primary and middle schools. We thank an anonymous referee for pointing out this problem.

${ }^{20}$ We only comment on the coefficients in Table 2; however, the effects of all the covariates both in size and in sign are very similar across Tables 1 and 2.

${ }^{21}$ It is beyond the scope of this paper to investigate the causes of sex-based differences in households' decisions about children's activities.

${ }^{22}$ Actually, public transportation might be related to school and working decisions, making it invalid as an instrument. However, the results are the same even after excluding public transportation from the set of instruments.

\section{References}

Akabayashi H. and Psacharopoulos G. (1999) 'The Trade-off between Child Labor and Human Capital Formation. A Tanzanian Case Study', Journal of Development Studies 35(5): 120-140.

Becker G. S. (1965) 'A Theory of the Allocation of Time', Economic Journal 75: 493-517.

Behrman J. R. and Knowles J. C. (1999) 'Household Income and Child Schooling in Vietnam', World Bank Economic Review 13(2): 211-256.

Brown D. K., Deardorff A. V. and Stern R. S. (2002) 'The Determinants of Child Labor: Theory and Evidence', Discussion Paper No. 486, University of Michigan. 
Canagarajah S. and Coulombe H. (1997) 'Child Labor and Schooling in Ghana', Policy Research Working Paper Series 1844, World Bank.

Cartwright K. (1999) 'Child Labor in Colombia' in Grootaert C. and Patrinos H. (eds.) The Policy Analysis of Child Labor. A Comparative Analysis, New York: St Martins Press: Chapter 4.

Cartwright K. and Patrinos H. A. (1999) 'Child Labor in Urban Bolivia' in Grootaert C. and Patrinos H. (eds.) The Policy Analysis of Child Labor. A Comparative Analysis. New York: St Martins Press.

Chernichovsky D. (1985) 'Socioeconomic and Demographic Aspects of School Enrollment and Attendance in Rural Botswana', Economic Development and Cultural Change 33: 319332.

Cigno A. and Rosati F. C. (2005) The Economics of Child Labor, Oxford: Oxford University Press.

Deb P. and Rosati F. C. (2002) 'Determinants of Child Labor and School Attendance: The Role of Household Unobservables', UCW Working Paper.

Demery L., Chao S., Bernier R. and Mehra K. (1995) 'The Incidence of Social Spending in Ghana', Poverty and Social Policy Discussion Paper No. 82, World Bank, Washington, DC.

Duraisamy P. (2002) 'Changes in Returns to Education in India, 1983-94: By Gender, Age-cohort and Location', Economics of Education Review 21(6): 609-622.

Edmonds E. V. (2007) 'Child Labor', IZA Discussion Paper 2606, Forthcoming in the Handbook of Development Economics, Volume 4.

Edmonds E., Pavcnik N. and Topalova P. (2007) 'Trade Adjustment and Human Capital Investments: Evidence from Indian Tariff Reform', Working Paper No. 12884 (National Bureau of Economic Research, Inc, USA).

Glewwe P. (1990) Improving Data on Poverty in the Third World: The World Bank's Living Standards Measurement Study, Washington, DC: World Bank.

Glewwe P. and Jacoby H. (1994) 'Student Achievement and Schooling Choice in Low-income Countries. Evidence from Ghana', Journal of Human Resources 29(3): 843-864.

Grootaert C. (1999) 'Social Capital, Household Welfare, and Poverty in Indonesia', World Bank Policy Research Working Paper No. 2148.

Grootaert C. and Kanbur R. (1995) 'Child Labor: A Review', Background Paper for the 1995 World Development Report on Labor, Washington, DC: World Bank.

Guarcello L., Lyon S., Rosati F. C. and Valdivia C. (2005a) 'Towards Statistical Standards for Children's Non Economic Work: A Discussion Based on Household Survey Data', Understanding Children's Work Working Paper, Italy.

Guarcello L., Rosati F. C., Lyon S. and Valdivia C. (2005b) 'Impact of Children's Work on School Attendance and Performance: A Review of School Survey Evidence from Five Countries', UCW Working Paper.

Hajivassiliou V., McFadden D. and Ruud P. (1996) 'Simulation of Multivariate Normal Rectangle Probabilities and Their Derivatives: Theoretical and Computational Results', Journal of Econometrics 72: 85-134.

Handa S. (2002) 'Raising Primary-school Enrolment in Developing Countries. The Relative Importance of Supply and Demand', Journal of Development Economics 69: 103-128.

Hazarika G. and Bedi A. (2003) 'Schooling Costs and Child Work in Rural Pakistan', Journal of Development Studies 39: 29-64.

Hazarika G. and Bedi A. (2006) 'Child Work and Schooling Costs in Rural Northern India', IZA DP 2136.

ILO (1996) Child Labour Surveys: Results of Methodological Experiments in Four Countries 1992-93, Geneva: International Labour Office.

ILO (2002) Youth, Training and Employment. Labour Overview. Latin America and the Caribbean, Geneva: ILO.

ILO (2006) The End of Child Labour: Within Reach, Geneva: ILO.

Kondylis F. and Manacorda M. (2006) 'School Proximity and Child Labor Evidence from Rural Tanzania', CEP Working Paper, 1537. 
Lavy V. (1996) 'School Supply Constraints and Children's Educational Outcomes in Rural Ghana', Journal of Development Economics 51: 291-314.

Norton A., Korboe D., Bortei-Dorku E. and Dogbe T. (1995) 'Poverty Assessment in Ghana Using Qualitative and Participatory Research Methods', Poverty and Social Policy Discussion Paper No. 83, World Bank, Washington, DC.

Orazem P. and Gunnarsson L. (2004) 'Child Labour, School Attendance, and Performance: A Review', Working Paper No. 04001 (Department of Economics, Iowa State University).

Patrinos H. A. and Psacharopoulos G. (1995) ‘Educational Performance and Child Labor in Paraguay', International Journal of Educational Development 15(1): 47-60.

Psacharopoulos G. and Yang H. (1991) 'Educational Attainment among Venezuelan Youth: An Analysis of Its Determinants', International Journal of Educational Development 11(4): 289-294.

Rodgers G. and Standing G. (1981a) 'Economic Roles of Children in Low-income Countries', International Labour Review 120(1): 31-47.

Rodgers G. and Standing G. (1981b) Child Work, Poverty and Underdevelopment, Geneva: International Labour Office.

Rosenzweig M. R. and Evenson R. (1977) 'Fertility, Schooling, and the Economic Contribution of Children in Rural India: An Econometric Analysis', Econometrica 45(5): 1065-1079.

Silva de la Luz M. (1981) 'Urban Poverty and Child Work: Elements for the Analysis of Child Work in Chile' in Rodgers G. and Standing G. (eds.) Child Work, Poverty and Underdevelopment, Geneva: International Labour Office.

Singh R. D. and Schuh G. E. (1986) 'The Economic Contribution of Farm Children and the Household Fertility Decisions: Evidence from a Developing Country, Brazil', Indian Journal of Agricultural Economics 41(1): 29-41.

Smith R. and Blundell R. (1986) 'An Exogeneity Test for a Simultaneous Equation Tobit Model with an Application to Labor Supply', Econometrica 54(2): 679-685.

Thomas D. (1990) 'Intra-household Resource Allocation: An Inferential Approach', Journal of Human Resources 25(4): 635-664.

Tienda M. (1979) 'Economic Activity of Children in Peru: Labor Force Behavior in Rural and Urban Contexts', Rural Sociology 44(2): 370-391.

UCW (2003) 'Understanding Children's Work in Nepal', Understanding Children's Work Working Paper, Italy.

UCW (2007) 'Measuring Child Labour: Discussion Note for Country Consultation in Cambodia', Understanding Children's Work Working Paper, Italy.

World Bank (1993) Investing in Health. World Development Indicators, Washington, DC: World Bank. 